Article

\title{
Outing the Elephants: Exploring a New Paradigm for Child Protection Social Work
}

\author{
Ian Hyslop ${ }^{1, *}$ and Emily Keddell ${ }^{2}$ \\ 1 Faculty of Education and Social Work, University of Auckland, Auckland 1023, New Zealand \\ 2 Department of Sociology, Gender and Social Work, University of Otago, P.O. Box 56, \\ Dunedin 9054, New Zealand; e.keddell@otago.ac.nz \\ * Correspondence: i.hyslop@auckland.ac.nz
}

Received: 9 April 2018; Accepted: 21 June 2018; Published: 25 June 2018

\begin{abstract}
This article sets out to trouble the psychologised and pathologising approach that has come to dominate child protection practice in Aotearoa-New Zealand and comparable societies. Within a neoliberal ideological frame, Governments deny the need to adjust markets, except in ways that remove protections from workers or specific vulnerable groups. In this context, social work is concerned with adjusting people to the discipline of the market. Within a risk-focused child protection paradigm, circumstances and behaviours associated with material deprivation are construed as indicators of heightened danger and harm to children as opposed to a means of better understanding family life. It is argued here that appreciation of how social inequality plays out in the lives of children and their families is critical to the development of more effective child protection social work. Poverty exacerbates the everyday struggle of parenting-it shames and disempowers, reducing confidence and perceptions of competence. With reference to contemporary Aotearoa-New Zealand, this article critiques current developments in child protection social work and outlines a new direction for development.
\end{abstract}

Keywords: child protection; neoliberalism; new paradigm; poverty; inequality

\section{Engaging with Complexity}

This article begins from the position that social work practice is politically located: that the mandate and methodology of social work is ideologically contested. The development of social work in child protection has, it seems, arrived at something of a fork in the road. It is contended that the impulse to over-simplify the complexity of child protection is counter-productive to the development of a more humane form of child and family practice (Munro 2010). Our aim is to identify some of the elements necessary for the design of a new practice vision which takes adequate account of the politically and economically situated nature of child protection social work. There is a specific focus on the Aotearoa-New Zealand (hereafter A-NZ) context and reference is made to comparable developments in England. It is suggested that parallels, and differences, between these settings-particularly in terms of efforts to address the over-representation of indigenous Māori children in all phases of child protection practice-may provide insights relevant to practice development in the wider Anglophone world.

In any critical discussion of contemporary child protection social work, it is fundamentally important to recognise the varied, inherent and dynamic tensions which impact upon the nature and quality of practice. The tap-root of these frictions is perhaps best understood as a function of the location of child and family social work at the interface between the regulatory state and the semi-autonomous role assigned to family life in liberal society (Lorenz 2017; Warner 2015). In practice, decision-making is a balancing exercise; an inexact process influenced by competing principles and guided by imperfect information 
(Berrick 2018). Workplaces are pressured, resources are limited, and media-fueled public expectations are both imperative and contradictory (Connolly and Doolan 2007).

Social work has a dual mandate: it is concerned with both the actions of individuals and the social context which shapes these actions. Arguably, the identity of the social work profession is distinguished by efforts to synthesise, in theory and practice, an analysis of individuated need and the structural determinants of disadvantage: the big and small picture of social life. Epstein (1999) describes social work as a "Janus-faced" endeavor.

For example, it is common to state the intentions of social work as helping people to accommodate to the status quo and as challenging the status quo by trying to bring about social change. This dissonance is intrinsic to social work, to its essence. (p. 9)

It will be suggested here that this conflicted orientation is relevant to an understanding of the challenges which confront contemporary child protection social work; a field that has become increasingly central to the identity of the profession (Bywaters et al. 2016a; Parton 2014a). It is argued that the key question is not simply about whether child abuse is attributed to dangerous or irresponsible parenting or understood as the product of wider socio-economic causes. The issue at hand is how this dual focus can be integrated. In our view, the capacity to operationalise an awareness of the relationship between structural inequality and private pain is the unrealised promise of child and family practice (Hyslop 2012; Gupta et al. 2018).

In keeping with the elephant-outing metaphor, the intent of the following discussion is to engage with the complexities that plague this terrain, and particularly the fraught relationship between child welfare and socio-economic inequality. Although the critique of contemporary child protection bureaucracies is well developed elsewhere (Featherstone et al. 2014) and the complex nature of the association between relative poverty and child protection is now being explored with some empirical rigor (Bywaters et al. 2018), the implications of this scholarship for everyday practice are less well articulated. In our view, the first step in this process requires a critical deconstruction of the contemporary relationship between social work, child protection and the neoliberal political project (Hyslop 2016).

\section{Social Construction and Child Welfare}

Forty years ago, W.H. Tawney observed that perceptions of socio-economic problems and preferred solutions are socially constructed.

It is merely to recall the commonplace that the tension between human wants and the limited resources available for satisfying them takes place, not in a vacuum, but in a specific cultural environment, by which the character, both of the wants and of the resources is determined. (Tawney 1978, p. 103)

Social work, particularly state social work, is embedded in a socio-economic-political context (Wallace and Pease 2011). The wider rationale for protective intervention in family life and the appropriate form of such engagement is culturally and politically sanctioned, rather than simply a matter of self-evident moral necessity or the outcome of dispassionate scientific understandings of cause and effect (Ferguson 2004; Gray and Webb 2013; Harding 1997; Warner 2015).

In relation to the design of new statutory practice processes, the introduction of fresh tools, or the elevation of practice principles such as the contemporary mantra of child-centred practice, it is critically important to pose the question, 'why now?' (Garrett 2009, p. 880). In our view, it is no coincidence that the child-centric practice emphasis that accompanies recent changes to the law and related practice frameworks for state social work in A-NZ has been accompanied by a renewed focus on parental responsibility for child well-being in a society riven by systemic social inequality (Hyslop 2017). As social class divisions have been magnified within a neoliberal policy rubric, there is increasing concern, at least among the academic social work community, that child protection 
practice may have become part of the problem rather than part of the solution to social exclusion (Featherstone et al. 2016).

\section{Child Protection, Inequality and the State}

Child protection practice has been transformed as the economic and political wind has shifted in A-NZ and comparable societies over the last thirty years (Wallace and Pease 2011). The visible relative poverty which accompanies unregulated capitalism has re-emerged in A-NZ and comparable societies (Crossley 2015; Jensen and Tyler 2015). In this political context, condemnation of the dependent poor has enjoyed a political re-birth. Social work has increasingly been recast as a mechanism of surveillance and intervention directed at problem populations (Spolander et al. 2015). Arguably, the associated policy drive for investment in individuated social capital is akin to a sophisticated repackaging of the late Victorian preoccupation with the social, moral and economic threat posed by the degenerate poor (Sugarman 2015).

In our view, it is also far too simplistic to view contemporary neoliberal child welfare policy as the betrayal of an earlier golden age of welfare state largesse. The function of state social work in the post war era is ambiguous and contested. The integrative 'fifth arm' of the liberal welfare state (Parton 2014b) can also be understood as a mechanism of control in a class society. Intervention has always been primarily directed at the lives of working-class children (Jones 1983). The supposedly enlightened welfare systems of the later twentieth century are now implicated in institutional abuse which has left a painful legacy, particularly for indigenous Māori in A-NZ (Stanley 2016).

However, the egalitarian humanist agenda (Philp 1979), if not the outcome, of much state social work in the welfare state era should also be recognised (Brodie et al. 2008; Parton 2014b). With reference to developments in A-NZ, it will be argued here that contemporary practice across the Anglophone world has been characterised by a retreat from this intent. It will be further argued that this vision can and should be reclaimed. Social work practice is distinguished by a close connection with the lived experience of citizens positioned at the margins of the liberal capitalist socio-economic system (Parton and O'Byrne 2000). This methodology potentially generates an awareness of the challenges faced by relatively impoverished people in unequal societies, exposing the pervasive myths of choice and personal culpability which support contemporary risk-driven and authoritarian child protection regimes (Featherstone et al. 2016).

Significantly for the purposes of this article, the contemporary liberal state has been reluctant to acknowledge the correlation between poverty and child maltreatment, preferring to focus on individual pathology rather than the role of social inequality. Gupta (2017) has described this inconvenient truth as the elephant in the room. Ironically, the absence of a simple causal link between poverty and child abuse has been used to justify this approach. The following statement is from the Honourable Paula Bennett, the then Minister for Social Development, in the foreword to the 2012 New Zealand Government White Paper for Vulnerable Children.

Though I acknowledge the pressure that financial hardship puts on families, that is never an excuse to neglect, beat, or abuse children. Most people in such circumstances do not abuse their children, and I cannot tolerate it being used as a justification to do so. (Bennett 2012, vol. 1, p. 2)

The inference is that recognition of the social stressors that may contribute to child maltreatment 'excuses' abusive behaviour. Featherstone et al. (2016) reveal the nuances that this reductive argument obscures.

For example, it is often asserted that the majority of people living in poverty do not neglect their children. This assertion not only supports notions of intentionality but also misunderstands the complexity of how parental identities are formed and maintained over time in the context of constraint and challenge. 
Paradoxically however, the material challenges and social deficits associated with parenting in poverty are routinely construed as risks in themselves, effectively associating social circumstances that are beyond the control of caregivers with a blaming discourse.

\section{Building a Neoliberal Narrative}

As Warner (2015) observes, social work and poverty are deeply enmeshed historically.

Since its earliest incarnations, social work has been inextricably bound up with poverty and with the complex and contradictory attitudes towards people living in poverty that have characterised social policy since the late 19th century. (p. 46)

Issues of race, gender and inequality are tangled with the operation of child protection systems in complex and subtle ways as opposed to being clear, linear and deterministic. In our view, effective child protection requires a deeper, more socially sensitive, understanding of these relationships and of the context in which they occur. The emotive discourse of risk and abuse, and the associated need to protect vulnerable children, carries immense tautological authority which can serve to camouflage the ideological dimensions of contemporary child protection.

The following is a necessarily broad-brush synopsis of the recent history of the statutory child protection system in A-NZ, with reference to comparable developments in England. It begins with the genesis and application of the Children, Young Persons and their Families Act, 1989 (recently amended as the Oranga Tamariki Act, 1989). This ground-breaking legislation entailed a commitment to childand family-centred practice in general and particularly for whanau Māori (extended family) who were identified as subject to personal and institutional racism in the seminal Puao Te Ata Tu report (Puao Te Ata Tu 1988). Although it was shaped by a variety of competing interests, the 1989 Act was fundamentally driven by a concern with inequality and specifically the over-representation of Māori children in institutional and out-of-family care. The compelling vision of the time was that whanau, hapu and iwi ${ }^{1}$ were likely to make safer decisions about the care of their children than professional groups, provided they were given sufficient authority, information and support in terms of appropriate social services and material assistance (Hyslop 1997).

Subsequently, the reformed law was administered in the harsh economic climate which accompanied the neoliberal political turn of the 1990s (Kelsey 1995). Although there was a significant commitment (at least initially) to making statutory social work services more responsive to the cultural identity of Mãori, the potentially transformative concept of bicultural governance which the Puao te Ata Tu report aspired to was not embraced at the wider Government level. In the arena of child protection intervention, a more culturally inclusive process of decision-making did not fundamentally address the social consequences of underlying economic disparities resulting from the history of colonisation and cultural alienation. At the level of casework intervention, the expectation that wider kin groups would assume care of their children was enforced, but the resources needed to successfully discharge this responsibility were often withheld. Over time, this process of demanding responsibility with minimal social assistance has frustrated the intent of the legislation and has, paradoxically, provided the justification for a retreat from the vision of whanau empowerment (Hyslop 2017).

The blitzkrieg of neoliberal economic reform was moderated in the first decade of the 2000s during a three-term period of Labour-led government. This political juncture has significant parallels with the 'third way' politics associated with the New Labour governments in the U.K. In A-NZ, a social development agenda focused on 'supply side' economic adjustments such as training for labour market readiness and incentivising low-paid work through tax credits (Lunt 2001). The concept of combatting social exclusion through the development of human capital was particularly pronounced in the English

1 These Māori language terms approximate to extended family (whanau), larger group of connected kin (hapu) and wider tribal identity (iwi). 
context, with an emphasis on the preparation of children to become future players in competitive global markets (Giddens 1998; Morel et al. 2012).

Several commentators (Featherstone et al. 2014; Parton 2014b; Warner 2015) suggest that the associated identification and surveillance of a group of 'failing' citizens laid the ground for a more punitive approach to families under the contemporary gaze of the child protection system: specifically, earlier removal and forced adoption. This policy orientation has developed in concert with other political and cultural tropes such as the demonization of the dependent under-class poor which accompanies times of economic insecurity (Cummins 2018; Jensen and Tyler 2015), and the specific scandal politics surrounding the death of baby Peter Connolly in 2007 (Warner 2013).

These influences have coalesced in a child protection policy emphasis on the moral responsibility of parents which, in turn, resonates in the popular appeal of trauma studies and prevention science research with its associated focus on the inter-generational transmission of poverty and disadvantage. Gillies et al. (2017) argue that the confluence of a social investment policy framework, brain science and corporate interest has justified a proliferation of parenting programmes targeted at impoverished mothers.

Left aside in the seemingly common sense and straightforward scenario of early intervention to save young brains is the unequal gendered, classed and raced environment in which parents and children live out their lives. (pp. 131-32)

A culture of poverty discourse masks the reality that structural disadvantage is an abiding and embedded outcome of exploitative capitalist economic relations (Krumer-Nevo 2017).

\section{Aotearoa-New Zealand Context}

The statutory child protection system in A-NZ has also been shaken by child death events over the last twenty years. The fact that Māori children figure disproportionately in these events, as they do in all points of contact with the system, has been a significant driver in shifting the narrative away from family empowerment and towards a child rescue paradigm. The storm which surrounded the death of the Kahui twins ${ }^{2}$ in 2006 provided a watershed moment comparable to the moral outrage generated by the Peter Connolly tragedy. Hackell (2016) identifies the conflation of several folk-devil typologies in the media furore surrounding the Kahui case: Māori ethnicity and welfare dependency in concert with gendered violence and moral failing.

While the concept of a dangerous child-abusing social residuum in England may also contain elements of racist discourse, Hackell argues that in A-NZ this repository of fear and loathing was specifically connected with the fantasy of a savage Māori underclass.

Between 1989 and the present, the racialized child protection narrative has transformed from a focus on the damage done to Māori children by state violence to the cost visited upon the state and wider society by dangerous families. (Hyslop 2017, p. 1809)

The 'othering' of a dangerous, brown-skinned, beneficiary underclass provides a populist narrative which denies and minimises the structural dimensions of social exclusion. In this climate, a culturally informed and family-centred model of practice came to be associated with a range of practice short-comings, particularly the re-abuse of children in kinship care (Expert Panel-Modernising Child Youth and Family 2015). In 2011, the incoming National-led (Conservative) government instigated a lengthy process of reform which entailed a Green Paper discussion document (Ministry of Social Development 2011) and a subsequent White Paper report on 'Vulnerable Children' (Bennett 2012) which emphasised the psychological and behavioural dimensions of vulnerability and maltreatment with a central focus on parental pathology. This was followed by a

2 These children died from injuries received in the care of family in South Auckland. 
politically directed Expert Panel review (Expert Panel-Modernising Child Youth and Family 2015) which resulted in a watering down of the legislative commitment to whanau-centric decision-making and a greater focus on child-centred, trauma-informed care and earlier permanency (Hyslop 2017).

The over-representation of Māori in the A-NZ child protection system is largely a product of how the historical legacy of colonisation, structural inequality and institutional racism continues to play out in the lives of individuals and families. Whanau care failings were generally related to inadequate resourcing of family decision-making processes. These realities are consistently absent from these official constructions of child protection deficiencies. The recent reform process was coloured by a social investment policy framework (New Zealand Productivity Commission 2015). The underlying insurance-based concept involves a ramping up of the social capital investment model into an individually focused drive to reduce the future liability generated by failing citizens, particularly state welfare recipients (Heckman 2006; Humpage 2016). The philosophy is that individuals can be targeted and re-moralised or their children can be placed elsewhere if intervention is unsuccessful.

The brief history presented here has sketched the neoliberal political shift in the rationale for statutory child protection social work in A-NZ: from a stance of addressing the racist history of state care practice by empowering family, to addressing the trauma visited upon future citizens by dangerous families. A socio-politically informed appreciation of institutional racism has been supplanted by psychologically situated understandings of trauma and attachment. Such understandings may usefully inform practice, but they are inadequate tools for grappling with the socio-political context of child maltreatment. In our view, understandings of socially configured causation, insight about how capitalist societies 'work' and how inequality is manifested in the lives of children and families, particularly in their relationship to the state, can and should be applied in child protection practice.

\section{Speaking Truth to Power}

Poor families are more likely to have contact with child protection systems for a complex variety of reasons. Relative deprivation involves greater social insecurity. A range of risks are associated with income poverty, deprived neighbourhoods, and with crowded or inadequate housing. These circumstances increase the likelihood of poorer health, education and well-being outcomes for the children of the poor. Stressors associated with parenting in poverty, including a lack of access to appropriate support services, are likely to impact upon the quality of parenting and increase, but do not accurately predict, the probability of maltreatment. Families from lower socio-economic groupings are also more likely to be subject to oversight from the public or quasi-public-sector workers who report child abuse concerns.

There is some contention in the academic literature regarding the impact of systemic bias in relation to class, ethnicity and gender in the reporting of abuse and the treatment of families once they enter state child protection systems (Bradt et al. 2014). It seems clear that families subject to a greater number of social risks may also be more likely to be subject to reporting and intervention bias (Bywaters et al. 2016b). In A-NZ, a disproportionate number of Māori children are reported to the child protection system and these children are also more likely to receive high-tariff responses. While Māori make up $28 \%$ of the child population, they account for $40 \%$ of those notified and made up $60 \%$ of the children in care in 2015 (Expert Panel-Modernising Child Youth and Family 2015). Māori are also negatively over-represented in all the socio-economic indices (Perry 2012; Ware et al. 2016). In a sense, this becomes a chicken-and-egg debate, but it does point to the need for a policy and practice paradigm that takes account of both bias and inequality.

Social workers and their managers are in a unique position to contribute to the development of such a framework. Arguably, the capacity to appreciate the relationship between social structure and the lives of families and individuals is what distinguishes social work as an applied social profession (Krumer-Nevo 2017; Hyslop 2013). We are afforded the opportunity to develop not only awareness of structural inequality at the societal level, but also insight into the ways in which the micro-physics of power are manifested at the level of family life. According to (Warner 2015, p. 160), the "in-between" 
positioning of social work also affords the opportunity to communicate the "politics of social suffering" to others. Dominelli (2004) describes the nature of the advocacy that can be informed and motivated by such insight.

Social workers engage clients in exchanging knowledge about their life experiences so that their voices can be heard, and their stories can expose the inadequacy of official constructions of their lives. By supporting the creation of counter discourses social workers assist those outside their circles to understand the world from client perspectives. (p. 38)

This critical voice and the 'public role' which social work potentially generates appear to have been significantly diminished in recent times (Cree 2013; Rogowski 2012). It has certainly been largely silenced in mainstream child protection practice and it is instructive to consider why this has come to pass. Child protection social work appears to have lost the capacity to articulate and apply the insights which are derived from engaging with families struggling with the burden of deprivation. In our view, it is time for child protection to open its eyes to what its practice reveals and to have the confidence to develop a more ethical model of practice.

While international social work organisations have embraced an aspirational commitment to the pursuit of social justice (Global Agenda 2014), child protection practitioners are increasingly focused on protecting the children of the poor rather than addressing the social conditions which foster unsafe environments in increasingly unequal societies (Parton 2014b). In late 2015, the hypocrisy of this position was openly articulated by a social worker (reported in The Guardian newspaper) in response to an address by the U.K. Chief social worker for children and families which aligned social work with social justice:

The role of the child protection social worker in today's world is not to strive to redress the imbalance of our society. And if the reality of what social workers do differs so radically from the ideology, then surely, it's time to look again at what we mean by social work and what the government and society expects of social workers? (Nicolas 2015, The Guardian, 20 October 2015)

We suspect that this instance of speaking truth to power resonates with the experience of many, if not most, statutory social workers. However, we also believe that naming and confronting this glaring disjunction can be the first step in re-introducing a social-work-informed understanding of the social into the practice of child protection social work specifically, and in the formation of public policy more generally.

A resurgent commitment to this inclusive humanist agenda is reflected in recent social work research and scholarship which has highlighted the incontrovertible but complex correlation between poverty and child maltreatment (Bywaters et al. 2016b; Davidson et al. 2017; Pelton 2015; Slack et al. 2017). Gillies et al. (2017) begin to consider how awareness of the relationship between deprivation and child welfare might be brought to the centre of child protection social work.

Supporting families to survive and thrive in this period of extended austerity should be a more central children's services priority, as a contribution to preventing fractured and damaging relationships in families and protecting children from their consequences. This objective has to be underpinned by wider economic and social policies. It has to inform staff education and training and be embedded in processes such as assessment and case review. (p. 8)

The following discussion will explore the case for the development of a child protection system that is more in tune with insights drawn from the engaged practice of social work as opposed to dispassionate risk recognition and treatment informed by a cognitive and behavioural science lens which disregards the symbiotic connection between poverty and wealth in capitalist societies. 


\section{Risk, Responsibility and Social Justice}

Featherstone et al. (2016) have identified the dominant child protection paradigm as a voracious risk monster which entraps us in a logic bubble and induces a form of analytical paralysis. To return to the November 2016 Guardian article highlighting the absence of any tangible relationship between contemporary child protection and distributive justice, the social worker concerned makes a further telling comment.

I became a social worker because of a strong feeling that the world is very unfair; some children are born with huge advantages and others huge disadvantages. Throughout my 23 years in child protection I have seen and done work to ensure children are protected and allowed to thrive, whoever they live with. The founding principle for children's social workers is "the welfare of the child is paramount". Perhaps social justice for the child, but certainly not for the family. (Nicolas 2015, The Guardian, 20 October 2015)—Italic emphasis added.

The clear implication is that there is an officially sanctioned place for social justice in statutory child protection. It is, however, a narrow conception which is compatible with a specific political and economic construction. If an idealised global capitalist marketplace is the organising principle of the social order, a socially just society is one which reproduces the idealised market subject: "the self-determining, networked individual liberated from gendered and classed expectations and ties" (Gillies et al. 2017, p. 34). Within this frame, the notion of individuated children's rights to a life free of abuse and neglect becomes something of a Trojan horse for a neoliberal socio-political agenda.

In our analysis, child protection social work must reject this ideologically assembled fallacy which runs so counter to the social insights that our profession produces. As Davidson et al. (2017) assert, distributive justice is, or should be, the central orientation of social work. Accordingly, social workers and policy makers need to reconstruct a practice of respect and openness: to effectively "change where they are sitting" (Featherstone et al. 2014, p. 112). Children are not individual products that need to be made market ready - they are enmeshed in the variably adequate shelter of their material circumstances, family constellations, cultural histories and community relationships.

Human identity and well-being is essentially collective; constituted in relationship to others. Sometimes family relationships are fragmented and impoverished, and sometimes they are dangerous. Even the most forthright critics of contemporary child protection systems are at pains to point out that they recognise that authoritative intervention is necessary in some situations to protect children from serious harm (Featherstone et al. 2014). However, this kind of crisis-related practice is exceptional and the child abuse detection and rescue paradigm that is derived from this imperative is no basis for a socially just child protection system. In the Aotearoa-New Zealand setting, the children who come to the attention of the statutory child protection system are drawn disproportionately from the brown proletariat —often young families, disproportionately young Māori and/or Pacific families, often women parenting alone-who are actively engaged in resisting their circumstances; struggling to live adequately (Hyslop 2017).

This structural insight is fundamental to social work and it has unavoidable political and ideological implications. Complicity with a focus on re-moralising the urban poor and/or saving their babies is not consistent with a commitment to reduce "rather than reflect or reinforce social inequality" (Bywaters et al. 2018, p. 60). Allied with this is the invisibility of everyday parenting within capitalist societies: the labour of parenting is neither seen nor valued, it is simply expected to be well-executed by someone-usually a woman-without the support of the state. Within the schema of neoliberalism, the ability of parents is measured by their capacity for independence from the state, and their ability to raise economically productive citizens. Instead of learning about how parenting is influenced by deprived circumstances, social workers are increasingly taught a more distant and clinical set of preferred practice knowledges, centred on the recognition of trauma and its effects.

We have argued that practice-centred relationships potentially produce a depth of understanding that transcends stereotyped and morally saturated accounts of self-responsibility for social failure; 
insight which lays bare the 'old libel' of behavioural poverty reproduction (Gordon 2011, p. 5, cited in Gillies et al. 2017, p. 163). This engaged sensibility needs to be reclaimed and realised in the practice of child protection social work: making the links between socio-political analysis and practice method (Gupta et al. 2018). It is time for social work to exercise some of its subversive potential, even if the message is unpalatable to our political and managerial masters. Child protection social work may not be a revolutionary activity, but it does not have to be alienating and innately oppressive. We need to consider how we might shift the balance of our practice towards a socially aware paradigm that involves more social care and less social control.

\section{How Might This Be Achieved?}

Child protection is a demanding and inexact craft, but we do this work a disservice if we do not engage with the wider socio-political reality: take account of the way in which capitalist societies are divided by exploitative social relations. In part, the sea-change that is needed simply involves adopting a fresh perspective which challenges the ideological constructions that have come to dominate child protection theory and practice in neoliberal times (Featherstone et al. 2014). With reference to the socio-economic determinants of neglect, Featherstone et al. (2016, pp. 6-7) embellish this point as follows.

A number of interconnected issues need addressing: the relationship between poverty and neglect and how child protection systems translate 'public issues' into 'private troubles' and, in doing so, convert them into evidence of intentionally troublesome/risky behaviour by parents.

In Aotearoa-New Zealand, a discourse of personal and family responsibility for the reproduction of trauma has become associated with both poverty reproduction and child maltreatment (Expert Panel-Modernising Child Youth and Family 2015). Psychologically grounded and traumainformed practice frameworks risk demonising and alienating service-users, discounting their wisdom. In relation to whanau Māori, this engagement requires more than cultural window-dressing. Dialogue needs to take account of the historical legacy of colonisation and the need for practice partnerships that provide both the responsibility and the material capacity to ensure safe outcomes.

Socially just practice and child protection social work are uncomfortable bed-fellows historically, but they are not irreconcilable. In terms of systemic bias, social workers need to understand that poverty can contribute to poor parenting while also recognising that poor parenting and parenting in poverty are not synonymous. We need to develop meaningful understandings of the stresses associated with social deprivation and the way in which these pressures impact upon security, trust, communication, choices, relationships, and the possibilities for change (Krumer-Nevo 2017). As Featherstone et al. (2016) argue, such an approach needs to be nested in a wider social model of policy and practice: a humanising orientation that recognises people as essentially social subjects rather than rational, context-free, neoliberal units. Gillies et al. (2017) propose that a socially just child protection lens would require the following.

It would mean greater recognition of the harm, distress and disadvantage poverty inflicts on children and families in the here and now. Rather than constructing policy and practice around individualised models that personalise and normalise inequality, initiatives would start from a framework of civil rights to housing, income thresholds, education, and health care services. More specifically, poverty and all its cumulative impacts would need to be acknowledged and addressed in terms of financial deprivation, as opposed to cultural or psychological deficits. (p. 161)

Such a change of perspective inevitably involves re-thinking the validity of risk-obsessed child protection systems; recognising that we have become over-organised and paralysed by risk, or more accurately by fear of the consequences of not assessing risk accurately (Stanley 2005). 
Relationships of openness and trust are difficult to develop and sustain in statutory practice, and they impact significantly on decision-making (Smith 2001). Gupta et al. (2018) discuss the impact of 'corrosive assumptions'. Messages of disrespect or coercion are conveyed insidiously across boundaries of class and ethnicity. Veltkamp and Brown (2017) qualitative study of the 'every day risk work' of Dutch child healthcare professionals found that similarities, or 'proximal' relationships', in terms of class and gender supported the development of 'we relationships' - where "common lived experiences and correspondingly shared stocks of knowledge facilitate familiarity and shared understanding" (p. 1300). In other words, it is easier for middle-class professionals to form trusting relationships with middle-class clients. In child protection practice, obstacles relating to class difference are often also further exacerbated by culture and ethnicity.

Both Krumer-Nevo (2017) and Gupta (2017) advocate for a poverty-informed social work that recognises and learns from the struggles, strengths, wisdom and rationality of those living with debilitating economic scarcity. This recognition includes taking account of the symbolic dimensions of poverty: the ways in which socially constructed shame and stigma can shape communication and influence relationships. It is also important to stress that these engaged understandings are not a matter of seeing the children of the poor as a "category apart"; of viewing families in poverty as a separate and dysfunctional class to be understood differently (Gillies et al. 2017, p. 24). Rather, it involves bringing social understandings back into the social work profession: recognising the reality that divergent structuring circumstances impact upon options and capacities in complex ways, including practices of struggle and resistance. To adapt Bourdieu's theorisation of the way in which social conditions become subtly embedded within individual subjectivities, social workers in child protection bureaucracies need to develop a feel for those who do not have a feel for the game (Garrett 2009).

A more progressive child protection paradigm requires political advocacy, policy shifts and practice reforms. Material support and practical help is often more useful than clinical assessment. This kind of political reorientation involves a commitment to a meaningful politics of redistribution and the re-building of family-centred social services. Parenting is difficult. Middle-class families are often able to purchase their way out of this pressure in a market model. Struggling families have an equal social right to meet their children's needs. Policies that provide for adequate basic income, housing and affordable quality child-care facilities are required. A lack of integrated social policy and accessible community support services means that poorer families are funneled into the child protection system; effectively as a social service of last resort.

The more that child protection social workers are distanced from the families they engage with, the more de-skilled and de-sensitised they become. Social workers need to get closer to people. We have been seduced by fear of getting too close, too complicit with the experience of the dangerous classes. The neoliberal social order is reinforced, effectively policed, by this kind of bureaucratised clinical practice at a distance. We need to have the audacity to reinvent the relational basis of social work in child protection; to destigmatise the intimidating risk juggernaut that our professional practice has become. This is not an injunction to naïve or unduly idealistic practice, but rather a call to engage meaningfully and get closer to the truth (Featherstone et al. 2016). We need to rethink child protection for the sake of children, families and for the heart and soul of the social profession.

Author Contributions: I.H. is the principal author of this critical commentary article. However, the analysis presented was developed in creative dialogue with E.K. E.K. had significant input into the generation of the argument presented here and into the crafting of the final text, particularly in relation to charting ways forward for socially and politically informed child protection practice in Aotearoa-New Zealand.

Conflicts of Interest: The authors declare no conflict of interest.

\section{References}

Bennett, Paula. 2012. The White Paper for Vulnerable Children. Wellington: Ministry of Social Development. Available online: https/ / www.childrensactionplan.govt.nz/the-white-paper (accessed on 19 March 2018). 
Berrick, Jill. 2018. The Impossible Imperative: Navigating the Competing Principles of Child Protection. Oxford: Oxford University Press.

Bradt, Lieve, Griet Roets, Rudi Roose, Yves Rosseel, and Maria Bouverne-De Bie. 2014. Poverty and decision making in child welfare and protection: Deepening the bias-need debate. British Journal of Social Work 45: 2161-75. [CrossRef]

Brodie, Ian, Chris Nottingham, and Stephen Plunkett. 2008. A tale of two reports: Social work in Scotland from social work in the community (1996) to changing lives (2000). British Journal of Social Work 38: 697-715. [CrossRef]

Bywaters, Paul, Lisa Bunting, Gavin Davidson, Jennifer Hanratty, Will Mason, Claire McCartan, and Nicole Steils. 2016a. The Relationship between Poverty, Child Abuse and Neglect: An Evidence Review. Coventry: Joseph Rountree Foundation.

Bywaters, Paul, Geraldine Brady, Tim Sparks, and Elizabeth Bos. 2016b. Child welfare inequalities: New evidence, further questions. Child E Family Social Work 21: 369-80. [CrossRef]

Bywaters, Paul, Geraldine Brady, Lisa Bunting, Brigid Daniel, Brid Featherstone, Chantel Jones, Kate Morris, Jonathan Scourfield, Tim Sparks, and Calum Webb. 2018. Inequalities in English child protection practice under austerity: A universal challenge? Child E Family Social Work 23: 53-61.

Connolly, Marie, and Mike Doolan. 2007. Responding to the deaths of children known to child protection agencies. Social Policy Journal of New Zealand 30: 1-11.

Cree, Viviene. 2013. New Practices of Empowerment. In The New Politics of Social Work. Edited by Mel Gray and Stephen A. Webb. Basingstoke: Palgrave MacMillan, pp. 145-58.

Crossley, Stephen. 2015. 'Realising the (troubled) family', 'crafting the neoliberal state'. Families, Relationships and Societies 5: 263-79. [CrossRef]

Cummins, Ian. 2018. Poverty, Inequality and Social Work. The Impact of Neoliberalism and Austerity Politics on Welfare Provision. Bristol: Policy Press.

Davidson, Gavin, Lisa Bunting, Paul Bywaters, Brid Featherstone, and Claire McCartan. 2017. Child Welfare as Justice: Why Are We Not Effectively Addressing Inequalities? British Journal of Social Work 47: 1641-51. [CrossRef]

Dominelli, Lena. 2004. Social Work: Theory and Practice for a Changing Profession. Cambridge: Polity Press.

Epstein, Laura. 1999. The culture of social work. In Reading Foucault for Social Work. Edited by Adrienne S. Chambon, Allan Irving and Laura Epstein. New York: Columbia University Press, pp. 3-26.

Expert Panel-Modernising Child Youth and Family. 2015. Final Report: Investing in New Zealand's Children and Their Families. Wellington: Ministry of Social Development. Available online: www.msd.govt.nz/documents/aboutmsd-and-our-work/work-programmes/investing-in-children-report.pdf (accessed on 2 February 2018).

Featherstone, Brid, Kate Morris, Sue White, and Susan White. 2014. Re-Imagining Child Protection-Towards Humane Social Work with Families. Bristol: Policy Press.

Featherstone, Brid, Anna Gupta, K. M. Morris, and Joanne Warner. 2016. Let's stop feeding the risk monster: Towards a social model of child protection. In Families Relationships and Societies. Bristol: Policy Press.

Ferguson, Harry. 2004. Protecting Children in Time: Child Abuse, Child Protection and the Consequences of Modernity. Basingstoke: Palgrave Macmillan.

Garrett, Paul Michael. 2009. Questioning Habermasian Social Work: A Note on Some Alternative Theoretical Resources. British Journal of Social Work 39: 867-83. [CrossRef]

Giddens, Anthony. 1998. The Third Way: The Renewal of Social Democracy. Cambridge: Polity Press.

Gillies, Val, Rosalind Edwards, and Nicola Horsley. 2017. Challenging the Politics of Early Intervention-Who's 'Saving' Children and Why. Bristol: Policy Press.

Global, Agenda. 2014. Global agenda for social work and social development: First Report-Promoting social and economic equalities. International Journal of Social Work 57: 3-16. [CrossRef]

Gray, Mel, and Stephen A. Webb, eds. 2013. The New Politics of Social Work. Basingstoke: Palgrave Macmillan.

Gupta, Anna. 2017. Poverty and child neglect-The Elephant in the Room? Families, Relationships and Societies 6: 21-36. [CrossRef]

Gupta, Anna, Hannah Blumhardt, and ATD Fourth World. 2018. Poverty, exclusion and child protection practice: The contribution of the politics of recognition and respect. European Journal of Social Work 21: 1-3. [CrossRef]

Hackell, Melissa. 2016. Managing anxiety: Neoliberal modes of citizen subjectivity, fantasy and child abuse in New Zealand. Citizenship Studies 20: 867-82. [CrossRef] 
Harding, Lorraine Fox. 1997. Perspectives in Child Care Policy, 2nd ed. London and New York: Longman.

Heckman, James J. 2006. Skill formation and the economics of investing in disadvantaged children. Science 312: 1900-2. [CrossRef] [PubMed]

Humpage, Louise. 2016. Income management in New Zealand and Australia: Differently framed but similarly problematic for Indigenous peoples. Critical Social Policy 36: 551-71. [CrossRef]

Hyslop, Ian. 1997. The Promise and the Practice: Child Protection Legislation in New Zealand. Asia Pacific Journal of Social Work 7: 56-67. [CrossRef]

Hyslop, Ian. 2012. Social Work as a Practice of Freedom. Journal of Social Work 12: 404-22. [CrossRef]

Hyslop, Ian. 2013. The "White Paper for Vulnerable Children" and the "Munro Review of Child Protection in England": A comparative critique. Aotearoa New Zealand Social Work 25: 4-14. [CrossRef]

Hyslop, Ian. 2016. Neoliberalism and Social Work Identity. European Journal of Social Work 21: 20-31. [CrossRef]

Hyslop, Ian. 2017. Child Protection in New Zealand: A History of the Future. British Journal of Social Work 47: 1800-17. [CrossRef]

Jensen, Tracey, and Imogen Tyler. 2015. 'Benefits broods': The cultural and political crafting of anti-welfare common sense. Critical Social Policy 35: 1-22. [CrossRef]

Jones, Chris. 1983. State Social Work and the Working Class. London and Basingstoke: Macmillan Press.

Kelsey, Jane. 1995. The New Zealand Experiment: A World Model for Structural Adjustment? Auckland: Auckland University Press.

Krumer-Nevo, Michal. 2017. Poverty and the political: Wrestling the political out of and in to social work theory, practice and research. European Journal of Social Work 20: 811-22. [CrossRef]

Lorenz, Walter. 2017. Social Work Education in Europe: Towards 2025. European Journal of Social Work 20: 331-21. [CrossRef]

Lunt, Neil. 2001. Winning hearts and minds for the Competition State. Policy Studies 31: 23-37. [CrossRef]

Ministry of Social Development. 2011. Green Paper for Vulnerable Children. Wellington: Ministry of Social Development.

Morel, Nathalie, Bruno Palier, and Joakim Palme. 2012. Towards a Social Investment Welfare State? Ideas Policies and Challenges. Bristol: The Policy Press.

Munro, Eileen. 2010. Review of Child Protection in England: Part One: A Systems Analysis. Available online: https: / /www.gov.uk/government/uploads/system/uploads/attachment_data/file/175407/TheMunroReviewPart_one.pdf (accessed on 10 December 2017).

New Zealand Productivity Commission. 2015. More Effective Social Services. Available online: https: / / www. productivity.govt.nz/inquiry-content/2032?stage=4 (accessed on 25 June 2018).

Nicolas, Joanna. 2015. Why Pretend Social Work Is about Social Justice/It's Not. The Guardian (Online), October 20. Available online: http:/ / www.theguardian.com/social-care-network/2015/oct/20/why-pretend-socialwork-is-about-social-justice-its-not(accessed on 15 July 2017).

Parton, Nigel. 2014a. The Politics of Child Protection: Contemporary Developments and Future Directions. Basingstoke: Palgrave Macmillan.

Parton, Nigel. 2014b. Social work, child protection and politics; some critical and constructive reflections. British Journal of Social Work 44: 2024-56. [CrossRef]

Parton, Nigel, and Patrick O’Byrne. 2000. Constructive Social Work: Towards a New Practice. Basingstoke: Palgrave Macmillan.

Pelton, Leroy H. 2015. The continuing role of material factors in child maltreatment and placement. Child Abuse Neglect 41: 30-39. [CrossRef] [PubMed]

Perry, Bryan. 2012. Household income in New Zealand; Trends in Indicators of Inequality and Hardship 1982-2011. Wellington: Ministry of Social Development. Available online: https://www.msd.govt.nz/.../householdincomes-report-2011-main-report (accessed on 10 February 2018).

Philp, Mark. 1979. Notes on the form of knowledge in social work. Sociological Review 27: 83-111. [CrossRef]

Puao Te Ata Tu. 1988. (Day break): The Report of the Ministerial Advisory Committee on a Māori Perspective for the Department of Social Welfare. Wellington: Ministry of Social Development.

Rogowski, Steve. 2012. Social work with children and families: Challenges and possibilities in the neoliberal world. British Journal of Social Work 42: 21-940. [CrossRef]

Slack, Kristen S., Lawrence M. Berger, and Jennifer L. Noyes. 2017. Introduction to the special issue on the economic causes and consequences of child maltreatment. Children and Youth Services Review 72: 1-4. [CrossRef] 
Smith, Carole. 2001. Trust and confidence: Possibilities for social work in 'high modernity'. British Journal of Social Work 31: 287-305. [CrossRef]

Spolander, Gary, Lambert Engelbrecht, and Annie Pullen Sansfaçon. 2015. Social work and macro-economic neoliberalism: Beyond the social justice rhetoric. European Journal of Social Work 19: 634-49. [CrossRef]

Stanley, Tony W. 2005. Making Decisions: Social Work Processes and the Construction of Risk(s) in Child Protection Work. Ph.D. thesis, Philosophy in Social Work, University of Canterbury, Christchurch, New Zealand.

Stanley, Elizabeth. 2016. The Road to Hell: State Violence against Children in Post-war New Zealand. Auckland: Auckland University Press.

Sugarman, Jeff. 2015. Neoliberalism and psychological ethics. Journal of theoretical and Philosophical Psychology 35 : 103-16. [CrossRef]

Tawney, Richard Henry. 1978. History and Society: Essays by R. H. Tawney. London: Routledge \& Keegan Paul.

Veltkamp, Gerlieke, and Patrick Brown. 2017. The everyday risk work of Dutch child-healthcare professionals inferring 'safe' and 'good' parenting through trust, as mediated by a lens of gender and class. Sociology of Health and Illness 39: 1297-313. [CrossRef] [PubMed]

Wallace, John, and Bob Pease. 2011. Neoliberalism and Australian social work: Accommodation or resistance? Journal of Social Work 11: 132-42. [CrossRef]

Ware, Felicity, Mary Breheny, and Margaret Forster. 2016. The politics of government 'support' in Aotearoa/New Zealand: Reinforcing and reproducing the poor citizenship of young Maori parents. Critical Social Policy 37: 499-519. [CrossRef]

Warner, Joanne. 2013. Social work, class politics in the moral panic over Baby P. Health, Risk and Society 15: 217-33. [CrossRef]

Warner, Joanne. 2015. The Emotional Politics of Social Work and Child Protection. Bristol: Policy Press.

(C) 2018 by the authors. Licensee MDPI, Basel, Switzerland. This article is an open access article distributed under the terms and conditions of the Creative Commons Attribution (CC BY) license (http:/ / creativecommons.org/licenses/by/4.0/). 